\title{
Panel Data Models of New Firm Formation in New England
}

\author{
Jitendra Parajuli ${ }^{1}$, Kingsley E. Haynes ${ }^{2}$ \\ ${ }^{1}$ George Mason University, Arlington, VA, USA \\ ${ }^{2}$ George Mason University, Arlington, VA, USA and Hong Kong University of Science and Technology, \\ Kowloon, HK, China
}

Received: 10 October 2016/Accepted: 9 August 2017

\begin{abstract}
This study examines the impact of the determinants of new firm formation in New England at the county level from 1999 to 2009. Based on the Spatial Durbin panel model that accounts for spillover effects, it is found that population density and human capital positively affect single-unit firm births within a county and its neighbors. Population growth rate also exerts a significant positive impact on new firm formation, but most of the effect is from spatial spillovers. On the contrary, the ratio of large to small firms in terms of employment size and the unemployment rate negatively influences single-unit firm births both within counties and among neighbors. However, there is no significant impact of local financial capital and personal income growth on new firm formation.
\end{abstract}

\section{Introduction}

Entrepreneurship is an important component of the US economy. Schramm (2004) suggested that the US is the leading entrepreneurial country in the world. New firms drive innovation and even during recessionary periods entrepreneurs provide impetus for recovery and economic growth. More recently, the US was ranked as the most entrepreneurial nation among 132 countries in the world and it was suggested that the US has entered a new innovation-driven stage of development (Acs et al. 2015).

Although the National Bureau of Economic Research (NBER) noted that the US experienced major economic contractions in 2001 and from late 2007 through mid-2009 (NBER 2009), the rate of new entrepreneurs (i.e., the percentage of adult population becoming entrepreneurs) has not changed abruptly. In 2001, this rate was $0.28 \%$ and from 2007 through 2009, it changed from $0.30 \%$ to $0.34 \%$ (Fairlie et al. 2016). However, such an aggregate index does not reflect the actual variation of entrepreneurial activities at the regional and local level. Moreover, spatial dependence and heterogeneity often mask local spatial patterns and spillovers (see Anselin 1988, LeSage, Pace 2009). This paper argues that while new firm formation is determined by the local characteristics of individual regions over time, it is also important to understand the effect of spatial externalities in firm births. Using fixed effects panel data models, this study examines the impact of the determinants of new firm formation in the high innovation region of New England - Connecticut, Maine, Massachusetts, New Hampshire, Rhode Island, and Vermont. This is done at the county level from 1999 through 2009 in order to capture local effects. 
This paper is arranged in the following sections. A theoretical background is presented in the next section (Section 2). Research methodology, data description, and information sources are presented in Section 3. The empirical results are provided in Section 4. Section 5 includes concluding remarks, policy recommendations, and directions for future research.

\section{$2 \quad$ Literature Review}

For various reasons, economic activities are not consistent across space and time. Following Marshall, Krugman (1991) argued that businesses agglomerate in a region because of the pooled labor market, production of non-tradable specialized inputs, and the possibility of greater productivity due to information spillovers. Agglomeration (Ellison, Glaeser 1999), area-based policy (Anyadike-Danes, O'Reilly 2005), cluster strategy (Delgado et al. 2010), and regional embeddedness (Dahl, Sorenson 2012) all influence business location decisions and the distribution of economic activities.

Population density is an important determinant of new firm births. According to Reynolds et al. (1994), urbanization and agglomeration are closely associated with population density and new firm formation rates are often positively associated with population density. Audretsch, Fritsch (1994) also found a positive relationship between population density (agglomeration) and new firm births. The percentage of entrepreneurial activity is higher in urban regions that are characterized by high population density (Bosma, Schutjens 2011). However, if a region has already maximized the benefits of urbanization, high population density can have negative impacts as well (Delfmann et al. 2014).

Human capital and entrepreneurship are closely associated with each other (Garvin 1983, Robinson, Sexton 1994, Davidsson, Honig 2003). Fritsch (1992) suggested that new business founders are highly skilled and Armington, Acs (2002) noted the importance of human capital on firm births. Regional variation in new firm formation, especially in the service sector, is contingent upon the availability of college-educated individuals that normally establish and manage new business ventures (Acs, Armington 2004). Likewise, human capital is crucial for innovation and information flow, and hence promotes new firm formation (Lee et al. 2004).

Financial capital is crucial for starting a new business. Personal, informal - acquaintances and angel investors - and/or formal financial institutions, such as banks, are often the sources of investment. Often, new businesses and entrepreneurs reap the benefits of the local financial environment where they were born or have lived for long time periods (Michelacci, Silva 2007, Robinson, Cottrell 2007, Dahl, Sorenson 2012). Sutaria, Hicks (2004) found a positive relationship between local bank deposits per capita and new firm formation. On the contrary, Kim et al. (2006) noted that potential entrepreneurs gain more from human capital and that financial capital is not a necessary condition for entrepreneurial ventures.

Establishment size is equally important for new firm formation. Audretsch, Fritsch (1994) examined the relationship between new firm births and mean establishment size using different frameworks and found both positive and negative association between them. In general, there is a negative association between average firm size and births in a region. That is, the larger the mean size of existing firms, the smaller the rate of new firm formation (Kangasharju 2000, Armington, Acs 2002, Lee et al. 2004). However, Sutaria, Hicks (2004) found that regions with larger firm size have faster firm birth rates.

The effect of unemployment on new firm formation is mixed. For instance, Reynolds et al. (1995) found a positive relationship between unemployment rate and firm births. Unemployed individuals can start new ventures in the earlier stages of unemployment. However, if unemployment persists for a long period, the propensity for self-employment declines (Ritsila, Tervo 2002). While Sutaria, Hicks (2004) found a negative relationship, Fritsch, Falck (2002) concluded that there is no relationship between new firm formation and unemployment. Storey (1991), Audretsch, Fritsch (1994), and Cheng, Li (2010) argued that depending on the type of estimation models, the unemployment rate can have both positive and negative association with new firm births.

Population growth also influences new start-ups. On the one hand, Audretsch, Fritsch

REGION: Volume 4, Number 3, 2017 
(1994), Davidsson et al. (1994), Guesnier (1994), Kangasharju (2000), and Armington, Acs (2002) noted that regional differences in firm birth rates can be explained by population growth. On the other hand, Sutaria, Hicks (2004) did not find any positive association between population growth and new firm formation and attributed the findings to modeling limitations.

Another predictor of new firm formation is per capita income growth. While Armington, Acs (2002) and Lee et al. (2004) found evidence of a positive effect, Sutaria, Hicks (2004) found no statistically significant effect of per capita income growth on new firm formation.

A number of studies have attested to the existence of spatial and temporal variation of entrepreneurship in the US. For instance, Armington, Acs (2002) suggested that entrepreneurial activities vary considerably across space, but not much over time. Acs, Mueller (2008) indicated that regional characteristics determine start-up rates. Urban, suburban, and rural differences in new business formation are also evident (Renski 2009). Parajuli, Haynes (2017) found that the spatio-temporal distributional patterns of single-unit firm births fluctuate in New England. In essence, whether within clusters, metropolitan areas, or states, new venture growth fluctuates over time and across space (see Guzman, Stern 2015, Morelix et al. 2016). Based on these findings, this study hypothesizes that the determinants of new firm formation influenced single-unit firm births within and across local areas (counties) in New England from 1999 through 2009 a period covering the "great recession".

Since the effect of individual determinants on new firm formation varies, based on the general findings, it is hypothesized that regions with higher population densities should experience higher firm births. The availability of higher human capital and local financial capital should also be positively associated with new firm formation. However, new firm formation should be negatively associated with the size of the existing firms in terms of employment. As the unemployment rate does not have any consistent effect on new firm formation, it is hypothesized that the relationship between the unemployment rate and new firm births is indeterminate. Finally, higher population growth rate as well as higher per capita income growth rate should be positively associated with new firm formation.

\section{Methodology and Data}

Unlike pure cross-sectional and time series analyses, the panel data technique offers various advantages, such as ability to control for individual heterogeneity and allows for more variability while reducing the issue of multicollinearity and providing more degrees of freedom (see Baltagi 2005). However, it should be noted that the distribution of a variable of interest - new firm formation - often exhibits spatial heterogeneity and spatial autocorrelation when cross-sectional observations - counties - are spatial units (see Anselin 1988). As the non-spatial panel model will not be able to capture such effects and since spatial interaction effects in the form of spillovers are expected, it is necessary to calibrate spatial panel models that allow one to account for such effects in relation to the new firm formation dynamics.

For a panel of $\mathrm{N}$ observations over time $\mathrm{T}$ periods with $\mathrm{K}$ explanatory variables, a spatial panel regression model that includes spatial effects is (see Elhorst 2003, 2014):

$$
Y_{t}=\rho W Y_{t}+\alpha \iota_{N}+X_{t} \beta+W X_{t} \theta+u_{t}
$$

where $u_{t}$ is the error component and is defined as:

$$
u_{t}=\lambda W u_{t}+\epsilon_{t}
$$

In equations (1) and (2), $Y_{t}$ is an $N T \times 1$ vector of the dependent variable, $\iota_{N}$ is a $N T \times 1$ vector of the constant terms, $X$ is an $N T \times K$ matrix of the independent variables, $\beta$ and $\theta$ are both $K \times 1$ vector of the coefficients, and $\epsilon$ is a $N T \times 1$ vector of error terms that are independent and identically distributed with mean zero and variance $\sigma^{2}$. In addition, $W$ is the spatial weight matrix of size $N \times N$, scalar $\rho$ is the spatial autoregressive term, and scalar $\lambda$ the spatial autocorrelation term.

The spatial weight matrix, $W$, describes the arrangement of possible interactions among spatial units. Such matrices could be based on the order of contiguity, inverse 
distance, or nearest neighbors (see Elhorst 2014). For example, the queen contiguity weight matrix accounts for common edges and vertices of contiguous spatial units with respect to the reference spatial unit. In the case of a non-normalized, first-order queen weight matrix that takes binary values ( 0 and 1$)$ weight coefficients assume 1 for the commonly shared edges and vertices in the immediate vicinity and 0 otherwise. The weight matrix is generally normalized for the ease of interpretation (see Elhorst 2014). As the spatial panel model takes into consideration spatial interactions based on the spatial weight matrix, in Equation (1), $W Y_{t}$ and $W X_{t}$ represent the spatially weighted dependent and independent variable in the matrix form, respectively.

Based on the value of $\rho, \lambda$, and $\theta$, different types of models can be specified:

- If $\lambda=0$ and $\theta=0$ : Spatial autoregressive model (SAR)

- If $\rho=0$ and $\theta=0$ : Spatial error model (SEM)

- If $\lambda=0$ : Spatial Durbin model (SDM)

- If $\lambda=0, \rho=0$, and $\theta=0$ : Non-spatial model

The global Moran's I statistic given by Equation (3) is used for examining spatial dependence (Bailey, Gatrell 1995).

$$
I=\frac{N \sum_{i=1}^{N} \sum_{j=1}^{N} w_{i j}\left(x_{i}-\bar{x}\right)\left(x_{j}-\bar{x}\right)}{\sum_{i=1}^{N}\left(x_{i}-\bar{x}\right)^{2}\left(\sum_{i \neq j} \sum w_{i j}\right)}
$$

where $w_{i j}$ is the element of weight matrix $W, x$ is the variable of interest, and $\bar{x}$ is the mean of $x$.

There are a number of issues that have to be accounted for while calibrating a panel data model. First, the fixed effects model is generally preferred when there is a specific set of cross-sectional observations and the inference is based on them instead of the sample drawn from the population (see Baltagi 2005). Thus, as this study is focused only on New England, the fixed effects models will be adopted. Second, firm births in a county are likely to affect firm births in the neighboring/contiguous counties. That is, there are direct and indirect effects associated with new firm formation and these impacts can be considered in the SAR and SDM techniques. Thus, both SAR and SDM will be calibrated. Based on the log-likelihood and Akaike Information Criterion (AIC), the appropriate model will be selected. Third, as noted earlier, as new firms provide impetus to growth even during recessions (Schramm 2004), rates of new entrepreneurs have not abruptly changed during the observation period (Fairlie et al. 2016), and entrepreneurial activities change more across regions than over time (Armington, Acs 2002), only county-specific effects will be considered. The XSMLE module in Stata will be used for the estimation purpose (Belotti et al. 2016).

Data at the county level used in this study come from three different sources the Census Bureau (CB), Bureau of Economic Analysis (BEA), and Bureau of Labor Statistics (BLS). The number of single-unit firm births, area (in square miles), public school enrollment, capital deposit (in US dollars) in local commercial and saving institutions, and establishment size in terms of employees are from the CB. Data from the BEA include per capital personal income (in US dollars), population, population growth rate, and per capita personal income growth. The unemployment rate was obtained from the BLS. Table 1 provides the details of variables.

\section{Empirical Results}

The temporal variations of single-unit firm births (in logarithm) by states in New England and by counties in Rhode Island are shown in Figure 1.

In New England, over the study period, Massachusetts and Vermont experienced the largest and smallest number of single-unit firm births, respectively. In addition, at the state level, new firm formation was generally declining between 2007 and 2009. This 
Table 1: Variable details

\begin{tabular}{lll}
\hline Variable & Description & Data Source \\
\hline $\begin{array}{l}\text { Dependent in } \\
\text { lsub }\end{array}$ & Logarithm & CB \\
Independent & in logarithm of single-unit firm birth & \\
lpopden & Logarithm of population density & BEA and CB \\
lpubenrpc & Logarithm of public enrollment per capita & BEA and CB \\
lfincappc & Logarithm of per capita deposit in local commercial & \\
& and savings institutions & \\
lestratiol & Logarithm of the ratio of establishments with 50 or & CB \\
& more employees to establishments with less than 10 & \\
employees & BLS \\
luempr & Logarithm of unemployment rate & \\
popgr & Population growth rate & BEA \\
perincgr & Per capital personal income growth rate & BEA \\
\hline
\end{tabular}

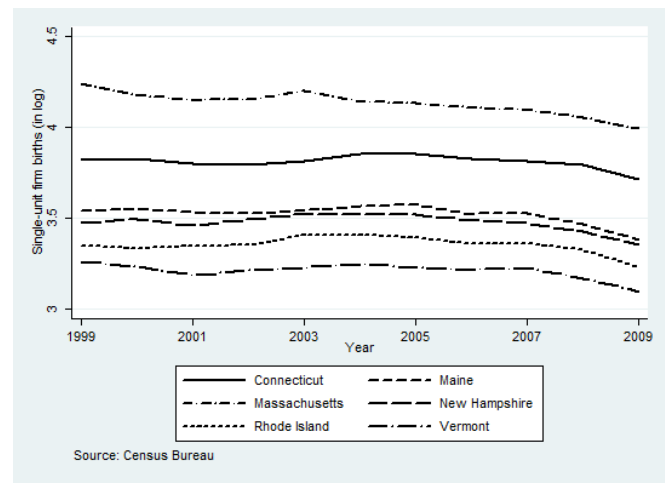

(a) State aggregate

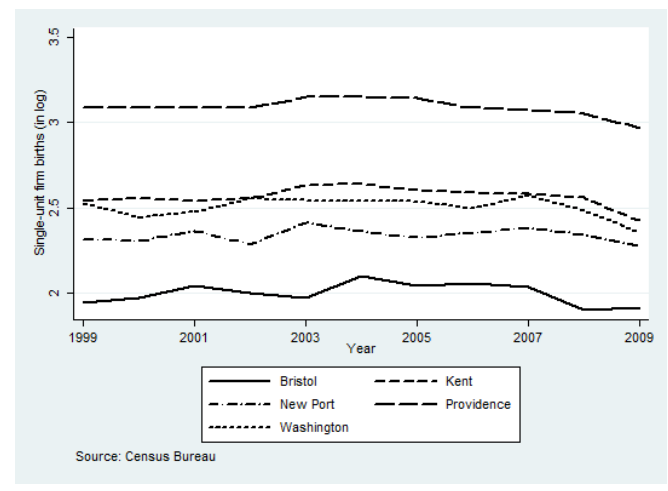

(b) County aggregate (Rhode Island)

Figure 1: Temporal variation of single-unit firm births

corresponded with the bottoming out of the great recession. As shown in Figure 1b, such a trend was also observable at the county level within a state.

The spatial distributions of single-unit firm births (in logarithm) in 1999 and 2009 in New England are shown in Figure 2.

The estimated values of two non-spatial regression models - pooled and fixed effects panel - with the logarithm of single-unit firm births as the dependent variable are shown in Table 2.

In order to select the appropriate model between the pooled and fixed effects model, the F-statistic is used. The null hypothesis is that the intercept term (individual effects) is constant across all counties (i.e., the model is "poolable") and the alternative hypothesis is that the intercept term varies across counties (see Baltagi 2005). The F-statistic for degrees of freedom $\mathrm{F}(64,643)$ is equal to 204.67 with $\mathrm{p}<0.000$. This suggests that, at $5 \%$ significance level, the null is rejected and the fixed effects model is chosen. Further, log-likelihood and AIC values also suggest that the fixed effects model is appropriate compared to the pooled model.

As the unit of observations is not randomly selected, the fixed effects estimation makes sense. It should also be noted that the observation period is short and hence unit root analysis of individual time series is often not effective (see Baltagi 2005).

The non-spatial fixed-effects panel model suggests that for the 65 counties in New Eng- 


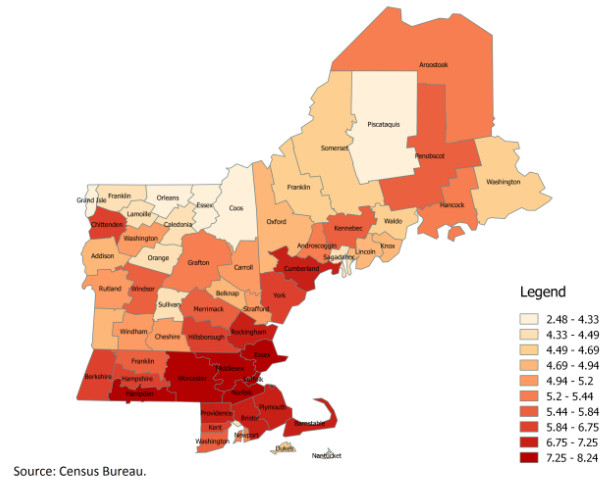

(a) 1999

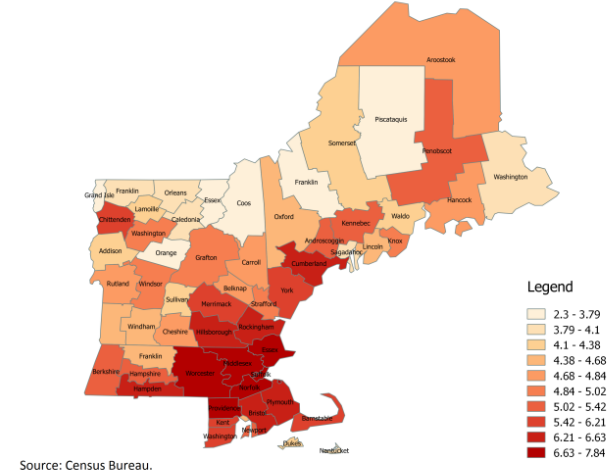

(b) 2009

Figure 2: Spatial variation of single-unit firm births in 1999 and 2009

land ${ }^{1}$ over the period of observation (1999-2009), controlling for other factors, population density, public enrollment, and personal income growth have a statistically significant positive correlation with single-unit firm births. On the contrary, establishment size and unemployment rate have a significant negative association with new firm formation while holding other variables constant. County level financial capital and population growth rates were not significantly associated with firm births.

Before calibrating the spatial fixed-effects panel models, the Moran's I statistics for all variables across the study period are calculated. The global Moran's I statistics based on the first-order queen contiguity weight matrix are presented in Table 3.

Except for the human capital variable, that is, the logarithm of public school enrollment per capita, the global Moran's I statistic of variables are generally positive and statistically significant in each observation period. The results imply that each variable is autocorrelated in space and that spatial dependence exists.

Table 4 shows the estimated values of the fixed effects SAR and fixed effects SDM in which the logarithm of single-unit firm births is the dependent variable. Based on the log-likelihood and AIC values, the preferred model is the fixed effects SDM.

In the fixed effects SDM, the spatial dependence associated with single-unit firm births $(\rho)$ is positive and statistically significant and suggests that new firm formation is spatially endogenous with respect to individual counties. Population density and public school enrollment per capita are both statistically significant and positively associated with single-unit firm births. Establishment size ratio is also statistically significant, but negatively associated with new firm formation.

Note that the SDM estimates are not interpreted as partial derivatives as in the classical regression technique. This is because a change in an explanatory variable in a county can impact single-unit firm births in other neighboring counties based on the spatial weight matrix (here, the queen contiguity matrix). Instead, the direct, indirect, and total effects as shown in Table 5 are interpreted (see LeSage, Pace 2009).

Population density has a positive direct and indirect impact on single-unit firm births. The difference between the coefficient estimate (0.945) and the direct effect estimate (1.109) is 0.164 , which reflects a positive feedback to a county itself. That is, an increase in population density results in an increase in the number of new firms within a county. The spatially lagged coefficient of population density is not significant, but the indirect effect is positive and statistically significant and has a magnitude that is almost twice the magnitude of the direct effect. This suggests a large spillover resulting from the population density of a county to nearby counties. The total impact is 3.220 and statistically significant. Thus, ceteris paribus, a 10 percent increase in population density would result in more than a 32 percent increase in new firm formation and that about $1 / 3$

\footnotetext{
${ }^{1}$ Although there are 67 counties in New England, this study only considers 65 contiguous counties.
} 
Table 2: Non-spatial regression models

\begin{tabular}{lrr}
\hline & Pooled & Fixed effects panel \\
\hline Intercept & $6.068^{* * *}$ & \\
lpopden & $(16.27)$ & \\
& $0.397^{* * *}$ & $1.215^{* *}$ \\
lpubenrpc & $(20.72)$ & $(3.48)$ \\
& $0.424^{*}$ & $0.304^{* * *}$ \\
lfincappc & $(2.23)$ & $(3.88)$ \\
& $0.234^{* * *}$ & 0.002 \\
lestratiol & $(4.44)$ & $(0.08)$ \\
& $0.839^{* * *}$ & $-0.315^{* * *}$ \\
luempr & $(13.18)$ & $(-5.25)$ \\
& 0.017 & $-0.266^{* * *}$ \\
popgr & $(0.21)$ & $(-8.18)$ \\
& 0.036 & 0.013 \\
perincgr & $(0.95)$ & $(1.28)$ \\
& $0.016 \dagger$ & $0.007^{* *}$ \\
Log-likelihood & $(1.82)$ & $(2.82)$ \\
AIC & -650.004 & 444.674 \\
Observation & 1316.008 & -873.348 \\
\end{tabular}

Source: Authors' calculations

Notes: Significant at $\dagger \mathrm{p}<0.1, * \mathrm{p}<0.05, * * \mathrm{p}<0.01,{ }^{*} * * \mathrm{p}<0.001 ; \mathrm{t}$-values in parentheses

of this would have resulted from the direct impact and the remaining from the spillover effects.

Similarly, a 10 percent increase in public school enrollment per capita results in a 6 percent increase in single-unit firm births. About 33 percent of the increase in new firm formation results from the direct impact and 67 percent from the indirect impact of human capital. The significant total impact of the population growth rate on new firm formation is 0.082 and almost all of that impact is comprised of spillover effects. Thus, for a 1 unit change in the population growth rate, single-unit firm births are expected to increase by more than 8 percent ceteris paribus.

Total effects of the establishment size ratio and the unemployment rate are both negative and statistically significant. Thus, for a 10 percent increase in the size of existing firms, new firm formation decreases by 6.6 percent and for a 10 percent increase in the rate of unemployment, new firm formation decreases by 3.1 percent. In addition, in the case of the establishment size ratio, both the direct and indirect impacts influence

Table 3: Global Moran's I statistics

\begin{tabular}{cccllllll}
\hline Year & lsub & lpopden & lpubenrpc & lfincappc & lestratiol & luempr & popgr & perincgr \\
\hline 1999 & $0.515^{* * *}$ & $0.764^{* * *}$ & -0.024 & $0.095 \dagger$ & $0.232^{* *}$ & $0.396^{* * *}$ & $0.314^{* * *}$ & $0.341^{* * *}$ \\
2000 & $0.504^{* * *}$ & $0.765^{* * *}$ & -0.072 & 0.075 & $0.261^{* * *}$ & $0.484^{* * *}$ & $0.356^{* * *}$ & $0.390^{* * *}$ \\
2001 & $0.522^{* * *}$ & $0.764^{* * *}$ & -0.067 & $0.079 \dagger$ & $0.254^{* * *}$ & $0.360^{* * *}$ & $0.351^{* * *}$ & $0.178^{*}$ \\
2002 & $0.522^{* * *}$ & $0.765^{* * *}$ & -0.098 & $0.106 \dagger$ & $0.244^{* *}$ & $0.287^{* * *}$ & $0.302^{* * *}$ & $0.143^{*}$ \\
2003 & $0.521^{* * *}$ & $0.765^{* * *}$ & -0.118 & $0.137^{*}$ & $0.242^{* *}$ & $0.412^{* * *}$ & $0.244^{* *}$ & $0.217^{* *}$ \\
2004 & $0.524^{* * *}$ & $0.765^{* * *}$ & -0.105 & $0.146^{*}$ & $0.216^{* *}$ & $0.559^{* * *}$ & $0.289^{* * *}$ & -0.003 \\
2005 & $0.522^{* * *}$ & $0.764^{* * *}$ & -0.091 & $0.118^{* *}$ & $0.219^{* *}$ & $0.610^{* * *}$ & $0.205^{* *}$ & $0.169^{*}$ \\
2006 & $0.541^{* * *}$ & $0.764^{* * *}$ & -0.093 & $0.144^{* *}$ & $0.242^{* *}$ & $0.547^{* * *}$ & 0.055 & $0.206^{* *}$ \\
2007 & $0.524^{* * *}$ & $0.764^{* * *}$ & -0.047 & $0.139^{* *}$ & $0.245^{* *}$ & $0.503^{* * *}$ & 0.051 & 0.024 \\
2008 & $0.510^{* * *}$ & $0.764^{* * *}$ & -0.097 & $0.141^{* *}$ & $0.189^{* *}$ & $0.569^{* * *}$ & $0.157^{*}$ & 0.021 \\
2009 & $0.540^{* * *}$ & $0.763^{* * *}$ & -0.078 & 0.052 & $0.207^{* *}$ & $0.513^{* * *}$ & $0.147^{*}$ & $0.365^{* * *}$ \\
\hline
\end{tabular}

Source: Authors' calculations

Notes: Significant at $\dagger \mathrm{p}<0.1,{ }^{*} \mathrm{p}<0.05,{ }^{* *} \mathrm{p}<0.01,{ }^{* * *} \mathrm{p}<0.001$ 
Table 4: Spatial panel models

\begin{tabular}{|c|c|c|}
\hline & Fixed effects SAR & Fixed effects SDM \\
\hline lpopden & $\begin{array}{r}0.781^{* *} \\
(2.77)\end{array}$ & $\begin{array}{r}0.945^{* *} \\
(2.98)\end{array}$ \\
\hline lpubenrpc & $\begin{array}{r}0.200^{* *} \\
(3.16)\end{array}$ & $\begin{array}{r}0.146^{*} \\
(2.25)\end{array}$ \\
\hline lfincappc & $\begin{array}{l}-0.001 \\
(-0.04)\end{array}$ & $\begin{array}{c}0.019 \\
(0.83)\end{array}$ \\
\hline lestratiol & $\begin{array}{r}-0.245^{* * *} \\
(-5.06)\end{array}$ & $\begin{array}{r}-0.260^{* * *} \\
(-5.37)\end{array}$ \\
\hline luempr & $\begin{array}{r}-0.138^{* * *} \\
(-5.04)\end{array}$ & $\begin{array}{l}-0.036 \\
(-0.75)\end{array}$ \\
\hline popgr & $\begin{array}{r}-0.001 \\
(0.16)\end{array}$ & $\begin{array}{l}-0.006 \\
(-0.71)\end{array}$ \\
\hline perincgr & $\begin{array}{r}0.003 \dagger \\
(1.67)\end{array}$ & $\begin{array}{c}0.002 \\
(1.02)\end{array}$ \\
\hline Lagged lsub $(\rho)$ & $\begin{array}{r}0.532^{* * *} \\
(15.65)\end{array}$ & $\begin{array}{r}0.497^{* * *} \\
(13.40)\end{array}$ \\
\hline $\mathrm{W}^{*}$ lpopden & & $\begin{array}{r}0.668 \\
(1.33)\end{array}$ \\
\hline $\mathrm{W}^{*}$ lpubenrpc & & $\begin{array}{r}0.160 \\
(1.35)\end{array}$ \\
\hline $\mathrm{W}^{*}$ lfincappc & & $\begin{array}{l}-0.016 \\
(-0.33)\end{array}$ \\
\hline $\mathrm{W}^{*}$ lestratiol & & $\begin{array}{l}-0.075 \\
(-0.73)\end{array}$ \\
\hline $\mathrm{W}^{*}$ luempr & & $\begin{array}{r}-0.117^{*} \\
(-1.97)\end{array}$ \\
\hline $\mathrm{W}^{*}$ popgr & & $\begin{array}{r}0.046^{* *} \\
(3.20)\end{array}$ \\
\hline $\mathrm{W}^{*}$ perincgr & & $\begin{array}{r}0.002 \\
(0.60)\end{array}$ \\
\hline Log-likelihood & 536.345 & 547.447 \\
\hline $\mathrm{AIC}$ & -1054.689 & -1062.894 \\
\hline Observations & 715 & 715 \\
\hline
\end{tabular}

Source: Authors' calculations

Notes: Significant at $\dagger \mathrm{p}<0.1,{ }^{*} \mathrm{p}<0.05,{ }^{* *} \mathrm{p}<0.01,{ }^{* * *} \mathrm{p}<0.001 ; \mathrm{t}$-values in parentheses.

single-unit firm births, while in the case of the unemployment rate; only the spillover effect is significantly associated with single-unit firm births.

Finally, there was no significant relationship or spillover effect associated with the availability of local financial capital and personal income growth rates with respect to new firm formation.

\section{Conclusion}

Entrepreneurial ventures are important for the US economy, and this paper examined the association between new firm formation and its determinants as well as the spillover effects in New England at the county level from 1999 through 2009 using both non-spatial and spatial panel data models. Based on the SDM, it was found that population density had the largest, positive impact on single-unit firm births both within a county and among its neighbors and that the spatial spillover was larger than the comparable direct effect on a county. This suggests that agglomeration and urbanization are conducive to new firm formation and that rural areas are less favorable for starting new businesses. Human capital - formal education, professional and managerial skills, information training, and 
Table 5: Estimated direct, indirect, and total effects

\begin{tabular}{lrrr}
\hline & Direct & Indirect & Total \\
\hline lpopden & $1.109^{* * *}$ & $2.111^{* *}$ & $3.220^{* * *}$ \\
& $(4.05)$ & $(2.62)$ & $(3.56)$ \\
lpubenrpc & $0.184^{*}$ & $0.416^{*}$ & $0.600^{*}$ \\
& $(2.44)$ & $(1.97)$ & $(2.41)$ \\
lfincappc & 0.019 & -0.010 & 0.009 \\
& $(0.69)$ & $(-0.10)$ & $(0.08)$ \\
lestratiol & $-0.290^{* * *}$ & $-0.372^{*}$ & $-0.662^{* *}$ \\
& $(-5.88)$ & $(-2.01)$ & $(-3.18)$ \\
luempr & -0.048 & $-0.264^{* * *}$ & $-0.312^{* * *}$ \\
& $(-1.04)$ & $(-3.97)$ & $(-4.25)$ \\
popgr & 0.002 & $0.080^{* *}$ & $0.082^{* *}$ \\
& $(0.26)$ & $(3.19)$ & $(2.76)$ \\
perincgr & 0.002 & 0.004 & 0.006 \\
& $(1.00)$ & $(0.77)$ & $(1.14)$ \\
\hline
\end{tabular}

Source: Authors' calculations

Notes: Significant at $\dagger \mathrm{p}<0.1,{ }^{*} \mathrm{p}<0.05,{ }^{*} * \mathrm{p}<0.01,{ }^{*} * \mathrm{p}<0.001 ;$ t-values in parentheses.

innovative abilities - is equally crucial for creating new ventures. A region with a high level of human capital will not only foster new firms within its boundary, but will also influence new firm formation in the neighboring areas. In addition, population growth is important in creating new start-ups both locally as well as in the nearby areas. This could be attributed to the fact that as the number of individuals increases, so does the demand for services and the potential entrepreneurs. A variety of earlier research findings support the results that population density, human capital, and population growth influence new firm formation (for example Fritsch 1992, Audretsch, Fritsch 1994, Reynolds et al. 1994, Armington, Acs 2002).

On the contrary, individuals are more likely to avoid the risk and uncertainties associated with new businesses and instead join existing firms that provide alternative employment and income-generation opportunities when such opportunities are available. Thus, as alternative establishment size increases, new firm formation decreases and such trends produce significant negative spillovers in neighboring areas. Similarly, as the rate of unemployment increases, single-unit firm births decrease. With increasing unemployment, individuals might migrate to other regions seeking opportunities or could rely on government welfare instead of starting opportunity or necessity based entrepreneurial ventures. Some earlier studies have found a significant negative association between new firm formation and establishment size as well as between firm births and unemployment (for example Armington, Acs 2002, Sutaria, Hicks 2004). Finally and unexpectedly, this study did not find any significant association between the availability of local financial capital or personal income growth with single-unit firm births.

A region endowed with various determinants of entrepreneurial ventures will not only influence itself, but its neighboring regions. Thus, rather than merely promoting policies to attract entrepreneurial ventures for economic growth and development, local/regional policymakers need to understand the nature of spatial externalities associated with new firm formation and should focus on how to benefit from them.

This study calibrated (non)spatial models using 65 contiguous counties and dropped two island counties. Future research should use other types of weighting schemes, such as distance- and nearest neighbor-based weight matrices, for the estimation purpose. However, it is hypothesized that the results would be similar. Moreover, as the focus was only on New England, future work should examine other regions of the US and may want to examine more explicitly the temporal considerations. While this study used the aggregate number of single-unit firm births, by disaggregating new firm formation by various industry sectors and calibrating sector-based panel models new insights related to economic structure might be provided. 


\section{Acknowledgement}

The authors would like to thank Roger R. Stough for the data on new firm formation. They are also grateful to the editors and anonymous reviewer for the constructive feedback.

\section{References}

Acs ZJ, Armington C (2004) The impact of geographic differences in human capital on service firm formation rates. Journal of Urban Economics 56: 244-278. CrossRef.

Acs ZJ, Mueller P (2008) Employment effects of business dynamics: Mice, gazelles and elephants. Small Business Economics 30: 85-100. CrossRef.

Acs ZJ, Szerb L, Autio E (2015) Global entrepreneurship index 2016. The Global Entrepreneurship and Development Institute, Washington, DC. https://www.researchgate.net/publication/284727510_Global_Entrepreneurship_Index_2016. CrossRef.

Anselin L (1988) Spatial econometrics: Methods and models. Kluwer, Dordrecht, The Netherlands. CrossRef.

Anyadike-Danes M, O'Reilly M (2005) Watch that space! The county hierarchy in firm births and deaths in the UK, 1980-1999. Small Business Economics 25: 273-292. CrossRef.

Armington C, Acs ZJ (2002) The determinants of regional variation in new firm formation. Regional Studies 36: 33-45. CrossRef.

Audretsch DB, Fritsch M (1994) The geography of firm births in Germany. Regional Studies 28: 359-365. CrossRef.

Bailey TC, Gatrell AC (1995) Interactive spatial data analysis. Pearson, Essex, UK

Baltagi BH (2005) Econometric analysis of panel data. John Wiley \& Sons, West Sussex, UK

Belotti F, Hughes G, Mortari AP (2016) Xsmle: Stata module for spatial panel data models estimation. https://ideas.repec.org/c/boc/bocode/s457610.html

Bosma N, Schutjens V (2011) Understanding regional variation in entrepreneurial activity and entrepreneurial attitude in Europe. Annals of Regional Science 47: 711-742. CrossRef.

Cheng S, Li H (2010) The effects of unemployment on new firm formation revisited: Does space matter? Regional Science Policy \& Practice 2: 97-120

Dahl MS, Sorenson O (2012) Home sweet home: Entrepreneurs' location choices and the performance of their ventures. Management Science 58: 1059-1071. CrossRef.

Davidsson P, Honig B (2003) The role of social and human capital among nascent entrepreneurs. Journal of Business Venturing 18: 301-331. CrossRef.

Davidsson P, Lindmark L, Olofsson C (1994) New firm formation and regional development in Sweden. Regional Studies 28: 395-410. CrossRef.

Delfmann H, Koster S, McCann P, van Dijk J (2014) Population change and new firm formation in urban and rural regions. Regional Studies 48: 1034-1050. CrossRef.

Delgado M, Porter ME, Stern S (2010) Clusters and entrepreneurship. Journal of Economic Geography 10: 495-518. CrossRef.

Elhorst JP (2003) Specification and estimation of spatial panel data models. International Regional Science Review 26: 244-268. CrossRef. 
Elhorst JP (2014) Spatial panel models. In: Fischer MM, Nijkamp P (eds), Handbook of Regional Science. Springer-Verlag, Heidelberg, Germany, 1637-1652. CrossRef.

Ellison G, Glaeser EL (1999) The geographic concentration of industry: Does natural advantage explain agglomeration? American Economic Review 89: 311-316. CrossRef.

Fairlie RW, Morelix A, Reedy EJ, Russell J (2016) The Kauffman index: Startup activity national trends. Ewing Marion Kauffman Foundation, Kansas City, MO, US, http://www.kauffman.org/ /media/kauffman_org/microsites/kauffman_index/startup_activity_2016/kauffman_index_startup_activity_national_trends_2016.pdf

Fritsch M (1992) Regional differences in new firm formation: Evidence from West Germany. Regional Studies 26: 233-241. CrossRef.

Fritsch M, Falck O (2002) New firm formation by industry over space and time: A multi-level analysis. Working Paper No. 11, Freiberg University of Mining and Technology, Freiberg, Germany. http://www.wiwi.unijena.de/uiw/publications/pub_1999_2003/fritsch_falck_2002.pdf

Garvin DA (1983) Spin-offs and the new firm formation process. California Management Review 25: 3-20. CrossRef.

Guesnier B (1994) Regional variations in new firm formation in France. Regional Studies 28: 347-358. CrossRef.

Guzman J, Stern S (2015) Where is silicon valley? Science 347: 606-609

Kangasharju A (2000) Regional variations in firm formation: Panel and cross-section data evidence from Finland. Papers in Regional Science 79: 355-373. CrossRef.

Kim PH, Aldrich HE, Keister LA (2006) Access (not) denied: The impact of financial, human, and cultural capital on entrepreneurial entry in the United States. Small Business Economics 27: 5-22. CrossRef.

Krugman P (1991) Increasing returns and economic geography. Journal of Political Economy 99: 483-499. CrossRef.

Lee SY, Florida R, Acs ZJ (2004) Creativity and entrepreneurship: A regional analysis of new firm formation. Regional Studies 38: 879-891. CrossRef.

LeSage J, Pace RK (2009) Introduction to spatial econometrics. CRC Press, Boca Raton, FL, US. CrossRef.

Michelacci C, Silva O (2007) Why so many local entrepreneurs. Review of Economics and Statistics 89: 615-633. CrossRef.

Morelix A, Reedy EJ, Fairlie RW, Russell J (2016) The Kauffman index: Startup activity state trends. Ewing Marion Kauffman Foundation, Kansas City, MO, US. http://www.kauffman.org/ /media/kauffman_org/microsites/kauffman_index/startup_activity_2016/kauffman_index_startup_activity_state_trends_2016.pdf

NBER (2009) US business cycle expansions and contractions. http://www.nber.org/cycles/cyclesmain.html

Parajuli J, Haynes KE (2017) An exploratory analysis of new firm formation in New England. In: Lombard J, Stern E, Clarke G (eds), Applied Spatial Modelling and Planning. Routledge, Abingdon, UK, 17-32

Renski H (2009) New firm entry, survival, and growth in the United States. Journal of the American Planning Association 75: 60-77. CrossRef.

Reynolds PD, Miller B, Maki WR (1995) Explaining regional variation in business births and deaths: U.S. 1976-88. Small Business Economics 7: 389-407. CrossRef. 
Reynolds PD, Storey DJ, Westhead P (1994) Cross-national comparisons of the variation in new firm formation rates. Regional Studies 28: 443-456. CrossRef.

Ritsila J, Tervo H (2002) Effects of unemployment on new firm formation: Micro-level panel data evidence from Finland. Small Business Economics 19: 31-40. CrossRef.

Robinson MJ, Cottrell TJ (2007) Investment patterns of informal investors in the Alberta private equity market. Journal of Small Business Management 45: 47-67. CrossRef.

Robinson PB, Sexton EA (1994) The effect of education and experience on self-employment success. Journal of Business Venturing 9: 141-156. CrossRef.

Schramm CJ (2004) Building entrepreneurial economies. Foreign Affairs 83: 104-115. CrossRef.

Storey DJ (1991) The birth of new firms: Does unemployment matter? A review of the evidence. Small Business Economics 3: 167-178. CrossRef.

Sutaria V, Hicks DA (2004) New firm formation: Dynamics and determinants. Annals of Regional Science 38: 241-262. CrossRef. 